\title{
MANAJEMEN MUTU PEMBELAJARAN PAI \\ DALAM UPAYA MEWUJUDKAN GENERASI BERAKHLAKUL KARIMAH DI SMK NEGERI 3 PURWOREJO
}

\author{
Zaenatun Sururiyah \\ (SMK Ma'arif NU 1 Bener Purworejo) \\ dezycollection@gmail.com
}

\begin{abstract}
ABSTRAK
Penelitian ini didasari oleh pentingnya akhlakul karimah. Sehubungan dengan hal tersebut, penelitian ini bertujuan untuk mengetahui Manajemen Pembelajaran PAI dalam Mewujudkan Generasi Berakhlakul Karimah di SMK N 3 Purworejo. Penelitian ini merupakan penelitian kualitatif. Pengumpulan data menggunakan wawancara, observasi, dan dokumentasi, dan keabsahan data menggunakan triangulasi, dan teknik analisis data meliputi reduksi data, penyajian data, dan penarikan kesimpulan. Hasil penelitian ini menunjukkan bahwa: (1) Perencanaan pembelajaran PAI dalam mewujudkan generasi berakhlakul karimah di SMK N 3 Purworejo dilakukan sebelum pembelajaran awal tahun dimulai. Dalam hal pembuatan perangkat mengajar, para guru membuat persiapan dengan membuat Program tahunan, Program semester, Silabus dan RPP menyesuaikan dengan materi dan arahan kepala sekolah. (2) Para guru mata pelajaran PAI di SMK N 3 Purworejo telah melaksanakan proses pembelajaran sesuai dengan apa yang telah dipersiapkan sebelumnya. Pelaksanaan pembelajaran dilakukan sesuai dengan kalender pendidikan, jadwal yang telah ditentukan, dan sesuai dengan Rencana Pelaksanaan Pembelajaran (RPP) yang telah dibuat. (3) Para guru yang mengajar PAI melaksanakan penilaian terhadap keberhasilan pembelajaran PAI dalam mewujudkan generasi berakhlakul karimah di SMK N 3 Purworejo dengan beberapa cara, di antaranya adalah dengan adanya ujian/test tertulis (penilaian harian dan akhir semester) dan penilaian sikap/akhlaq siswa dalam kehidupan sehari-hari. Standar yang dijadikan sebagai alat ukur penilaian keberhasilan santri dalam belajar pembelajaran PAI adalah perubahan sikap santri dan praktiknya dalam bersikap, berbicara, bertingkah laku, dan perubahan sikap santri terhadap guru dalam kehidupan sehari-hari. (4) Setiap guru PAI melakukan tindak lanjut pembelajaran dengan melaporkan hasil pembelajaran pada setiap mata pelajaran yang diampu kepada kepala sekolah. Pelaporan hasil pembelajaran dilakukan setiap semester. Hasil pembelajaran yang berupa penilaian akan direkap dan dilaporkan baik secara lisan maupun secara tertulis. Hasil pembelajaran juga disampaikan oleh para wali kelas secara langsung kepada orang tua/wali siswa pada saat pengambilan buku laporan hasil belajar.
\end{abstract}

Kata kunci: Manajemen Pembelajaran, PAI, Akhlakul Karimah

\section{PENDAHULUAN}

Manajemen mutu pembelajaran pendidikan agama Islam, mungkin merupakan kata yang sering didengar, bahkan dikerjakan, akan tetapi banyak yang mungkin belum paham sepenuhnya makna dari definisi manajemen pembelajaran PAl tersebut. Maka dari itu harus diketahui apa sesungguhnya makna atau definisi dari manajemen pendidikan Islam. Ada bermacam-macam pendapat yang mengemukakan tentang definisi manajemen pendidikan islam, oleh karena itu memerlukan kesepakatan terlebih dahulu apa yang dimaksud dengan manajemen pendidikan Islam.

Sejalan dengan perubahan jaman modern ini tentang pengetahuan manajemen yang harus diketahui, maka dari itu harus mengetahui apa sesungguhnya definisi dari manajemen itu sendiri. Manajemen pendidikan agama Islam berkaitan erat dengan 
masalah pengelolaan dalam sebuah lembaga pendidikan, terutama pendidikan Islam, di dalam dunia pendidikan tentunya dibutuhkan sebuah prngelolaan yang baik, karena maju berkembangnya dalam sebuah lembaga pendidikan tergantung dari sistem pengelolaan manajemennya.

Kemajuan suatu sekolah dengan sekolah lain tidaklah sama. Ada sekolah yang memiliki segudang prestasi dan ada pula yang sangat miskin dengan prestasi, ada sekolah yang sudah memiliki fasilitas yang lengkap dan ada pula yang memiliki sarana dan prasarana yang tidak layak untuk digunakan dalam proses kegiatan belajar mengajar, ada sekolah yang mempunyai manajemen sekolah yang baik dan ada pula sekolah yang memiliki manajemen yang kurang baik. Semua perbedaan itu terdapat banyak faktor yang melatar belakanginya.

Faktor yang dapat melatar belakangi antara lain yaitu: faktor tempat berdirinya sekolah, antara sekolah yang berada di pedesaan atau di perkotaan dan di daerah pedalaman pasti akan berbeda baik sarana prasarana, sumber daya manusia, ataupun manajemen yang ada di suatu sekolah. Selain itu, faktor yang cukup berpengaruh adalah faktor kepemimpinan kepala sekolah.

Dalam pandangan ajaran Islam, segala sesuatu harus dilakukan secara rapi, benar, tetrtib dan teratur. Proses-prosesnya harus diikuti dengan baik.Sesuatu tidak boleh dilakukan secara asal-asalan.Hal ini merupakan prinsip utama dalam ajaran Islam. Rasulullah SAW bersabda dalam sebuah hadits yang diriwayatkan Imam Thabrani, yang artinya "Sesungguhnya Allah sangat mencintai orang yang jika melakukan sesuatu pekerjaan, dilakukan sacara Itqan (tepat, terarah) jelas dan tuntas (HR thabrani).

Arah pekerjaan yang jelas, landasan yang mantap dan cara-cara mendapatkannya yang transparan merupakan amal perbuatan yang dicintai Allah SWT. Sebenarnya manajemen dalam arti mengatur segala sesuatau agar dilakukan dengan baik,tepat dan tuntas merupakan hal yang disyariatkan dalam ajaran Islam. Demikian pula dalam hadits riwayat Imam Muslim, yang artinya" Allah SWT mewajibkan kepada kita untuk berlaku ihsan dalam segala sesuatu"(HR Muslim).

Kata ihsan bermakna melakukan sesuatu secara maksimal dan optimal. Tidak boleh seorang muslim melakukan sesuatu tanpa perencanaan, tanpa adanya pemikiran, dan tanpa adanya penelitian, kecuali sesuatu yang sifatnya emergency. Akan tetapi, pada umumnya dari hal yang kecil hingga hal yang besar, harus dilakukan secara ihsan, secara optimal, secara baik, benar dan tuntas.

Setiap organisasi memiliki aktivitas-aktivitas pekerjaan tertentu dalam rangka mencapai tujuan organisasi. Dengan pengetahuan manajemen pendidikan Islam, bisa mengangkat dan menerapkan prinsip-prinsip dasar serta ilmu yang ada dalam Al Qur'an dan Hadis ke dalam lembaga pendidikan Islam. 
Manajemen sebagai ilmu yang baru dikenal pada pertengahan abad ke-19, dewasa ini sangat sangat populer, bahkan dianggap sebagai kunci keberhasilan pengelola sekolah atau lembaga pendidikan, baik lembaga pendidikan umum maupun lembaga pendidikan Islam. Bahkan ada orang yang menganggap manajemen pendidikan Islam sebagai suatu "ciri" dari lembaga pendidikan Islam modern,karena dengan adanya manajemen pendidikan Islam maka lembaga pendidikan akan berkembang dan berhasil.

Seorang peneliti barat yang terkenal menegaskan, bahwa "Tidak sedikitpun dalam Islam yang menghambat kemajuan.Soalnya,hanya karena beberapa waktu lamanya umat kristen telah mendapatkan sesuatu modus vivendi untuk hidup modern, sedangkan umat Islam belum sampai ke situ walaupun justru inilah proses yang sedang dilaksanakan". Jadi dengan keterangan ini maka ilmu dan ketrampilan manajemen pendidikan Islam merupakan salah satu senjata ampuh (modus vevendi) untuk mengejar ketinggalan kita. Keterbelakangan ini harus segera ditanggulangi. Tembok kebodohan, keterbelakangan ini harus segera ditumbangkan, dengan menciptakan manajer-manajer di lembaga pendidikan Islam yang bertanggung jawab (mas"uliyah), untuk memenuhi tuntutan umat guna menciptakan kebahagiaan hidup material, kultural, dan spiritual, di dalam suatu negeri yang indah baik dan diridhoi Allah (baldatun thayyibatun wa rabbun ghafur).

Pendidikan mempunyai tugas menyiapakan sumber daya manusia untuk pembangunan. Pendidikan Islam di Indonesia seringkali berhadapan dengan berbagai problematika yang tidak ringan.Diketahui bahwa sebagai sebuah sistem pendidikanIslam yang mengandung berbagai komponen yang antara satu dan lainnya saling berkaitan. ${ }^{50}$ Komponen pendidikan tersebut meliputi landasan, tujuan, kurikulum, kompetensi dan profesionalisme guru, pola hubungan guru murid, metodologi pembelajaran, sarana prasarana, evaluasi pembiayaan dan lain sebagainya. berbagai komponen yang terdapat dalam pendidikan ini seringkali berjalan apa adanya, alami dan tradisional, karena dilakukan tanpa perencanaankonsep yang matang. Akibat dari keadaan demikian, maka mutu pendidikan Islam seringkali menunjukkan keadaan yang kurang menggembirakan.

Landasan dan dasar pendidikan Islam yaitu Al-quran dan Al Sunnah belum benarbenar digunakan sebagaimana mestinya. Hal ini sebagai akibat belum adanya sarjana dan pakar di Indonesia yang secara khusus mendalami pemahaman Al quran dan Al-Sunnah yang berhubungan dengan pendidikan secara baik. Akibatnya pelaksana pendidikan Islam belum berjalan di atas landasan dan dasar ajaran Islam itu sendiri. Sebagai akibat dari kekurangan tersebut di atas, maka tujuan dan visi pendidikan Islam juga masih belum berhasil dirumuskan dengan baik. Tujuan pendidikan Islam seringkali diarahkan untuk menghasilkan manusia-manusia yang hanya menguasai ilmu Islam saja, dan visinya diarahkan untuk mewujudkan manusia yang salih dalam arti yang taat beribadah dan gemar beramal untuk tujuan akhirat.

\footnotetext{
${ }^{50}$ Umar Tirtarahardja dan La Sula, Pengantar Pendidikan, (Jakarta: Rineka Cipta, 2000), hlm. 225.
} 
Akibatnya dari keadaan yang demikian ini, maka lulusan pendidikan Islam hanya memiliki kesempatan dan peluang yang terbatas,yaitu hanya memiliki kesempatan dan peluang yang terbatas, yaitu hanya sebagai pengawal moral bangsa. Mereka kurang mampu bersaing dan tidak mampu berebut peluang dan kesempatan yang tersedia dalam memasuki lapangan kerja.Akibat lebih lanjut lulusan pendidikan Islam semakin tak berdaya. Keadaan yang demikian merupakan masalah besar yang perlu segera diatasi, lebih-lebih lagi jika dihubungkan dengan adanya persaingan yang makin kompetitif pada era globalisasi. ${ }^{51}$

Masalah akhlak sekarang ini memang sangat banyak sekali meminta perhatian dari para pendidik, alim ulama, pemuka masyarakat dan orang tua. Sering kali mendengar keluhan orang tua yang merasa kebingungan menghadapi anak-anaknya yang susah patuh, keras kepala, dan kurangnya sopan santun. Dan tidak sedikit para kyai dan ustadz yang merasa kebingungan menghadapi santri- santri yang seenaknya sendiri dalam mengikuti kegiatan di pondok pesantren.

Banyak orang yang mengatakan bahwa semua itu disebabkan oleh merosotnya akhlak manusia. Oleh sebab itu, masalah ini sudah selayaknya menjadi obyek pemikiran bersama Para ustadz, kyai, pendidik di sekolah, orang tua, pemerintah dan masyarakat. Pada umumnya semua harus bekerja sama mengusahakan penanggulanganya jangan hanya diserahkan kepada orang tua dan para ustadz saja.

Usaha untuk menanggulangi kemerosotan akhlak itu telah banyak dilakukan baik oleh lembaga keagamaan, pendidikan, sosial, dan instansi pemerintah. Namun hasil dari pembendungan arus yang berbahaya itu belum tampak, bahkan yang terjadi adalah sebaliknya.

Akhlak merupakan buah islam yang bermanfaat bagi manusia dan kemanusiaan serta membuat hidup dan kehidupan menjadi baik. Akhlak merupakan alat kontrol psikhis dan sosial bagi individu dan masyarakat. Akhlak adalah fungsionalisasi agama, artinya keberagaman menjadi tidak berarti jika tidak dibuktikan dengan akhlak. ${ }^{52}$

Tanpa akhlak, manusia tidak akan berbeda dengan binatang. Akhlak merupakan tahap ketiga dalam beragama. Tahap pertama, menyatakan keimanan dengan mengucapkan kalimat syahadat. Tahap kedua, menjalankan syariah dan menunaikan ibadah seperti shalat, zakat, puasa, dan berdo'a. Tahap ketiga, sebagai buah dari keimanan dan ibadah adalah akhlak.

Anak dalam perspektif Islam adalah amanah dari Allah SWT. Semua orang tua berkewajiban untuk mendidik anak-anaknya agar menjadi anak yang sholeh, berilmu dan bertaqwa. Pendidikan anak merupakan tanggung jawab setiap orang tua. Anak

\footnotetext{
${ }^{51}$ Sulistyorini, ManajemenPendidikan Islam, (Yogyakarya: Teras, 2009), hlm. 4-5.

${ }^{52}$ Dirjen Binbaga Agama Islam Depag RI, Metodologi pendidikan Agama Islam, (Jakarta: Depag RI, 2002), hlm. 74.
} 
merupakan mutiara bagi setiap orang tuanya. Selain sebagai penerus generasi, anak juga diharapkan menjadi manusia unggul, lebih dari apa yang dicapai oleh ayah dan ibunya. Keunggulan seseorang tidak diperoleh secara tiba-tiba, tapi memerlukan bimbingan yang terus-menerus. ${ }^{53}$ Anak yang tumbuh dan berkembang secara normal dapat dilihat dari bakat yang di miliki oleh anak antara lain mampu memahami dirinya dan pandai menyikapi permasalahan yang ada di sekelilingnya. ${ }^{54}$

Akhlak ataupun budi pekerti memang memegang peranan penting dalam kehidupan manusia. Akhlak yang baik akan membedakan antara manusia dengan hewan. Manusia yang berakhlak mulia dapat menjaga kemuliaan dan kesucian jiwanya, dan dapat mengalahkan tekanan hawa nafsu syahwat syaithaniah, berpegang teguh kepada sandisandi keutamaan, serta menghindarkan diri dari sifat-sifat kecurangan, kerakusan dan kedzaliman. 55

Manusia yang berakhlak mulia, suka tolong menolong sesama insan dan makhluk lainya. Mereka senang berkorban untuk kepentingan bersama, yang kecil hormat kepada yang tua, yang tua kasih sayang kepada yang kecil. Manusia memiliki budi pekerti yang mulia, senang kepada kebenaran dan keadilan, toleransi, mematuhi janji, lapang dada, dan tenang dalam menghadapi segala halangan dan rintangan.

Penanaman akhlak harus dimulai sejak kecil melalui contoh-contoh kehidupan di rumah tangga, lingkungan, pesantren maupun di sekolah. Bila nilai-nilai pendidikan akhlak yang baik telah tertanam di jiwa anak, maka anak tidak akan mudah di pengaruhi oleh hal yang negatif dan rasa cinta terhadap pendidikan Agama Islam yang akan terus tertanam dalam kehidupannya, misalnya dengan cara orang tua memberikan teladan bagi anakanaknya seperti shalat, puasa, dan sebagainya.

Pendidikan Agama Islam sebagai upaya sadar dan terencana dalam menyiapkan peserta didik untuk mengenal, memahami, menghayati, hingga mengimani, bertaqwa dan berakhlak mulia dalam mengamalkan ajaran agama Islam dari sumber- sumber, utamanya kitab suci Al-Qur'an dan Hadits melalui kegiatan bimbingan, pengajaran, latihan, dan penggunaan pengalaman yang di barengi dengan tuntunan untuk menghormati penganut agama dalam hubungannya dengan kerukunan antar umat beragama dalam masyarakat hingga terwujud kesatuan dan persatuan bangsa. ${ }^{56}$

\footnotetext{
${ }^{53}$ Rose Mini dan A. Priyanto, Perilaku Usia Dini Kasus danPemecahannya. (Yogyakarta: Kanisius, 2003), hlm. 24 .

${ }^{54}$ Jaudah Muhammad Awwad, Mendidik Anak Secara Islami, (Jakarta: Gema Insan, 1995), hlm. 25.

${ }^{55}$ Abdullah Nasih Ulwan, Pedoman Pendidikan Anak dalam Islam, (Semarang: Asy Syifa', 1981), hlm. 214.

${ }^{56}$ Departemen Pendidikan Nasional, Standar Kompetensi PendidikanAgama Islam, (Jakarta: Depdiknas, 2003), hlm. 7.
} 
Dengan pendidikan Agama Islam yang benar dan berkualitas, individu- individu yang beradab akan membentuk yang akhirnya memunculkan kehidupan sosial yang bermoral.Sekarang kebanyakan institusi-institusi pendidikan, khususnya institusi pendidikan Islam, walaupun memiliki kualitas dan fasilitas. Namun belum mampu memproduksi individu-individu yang beradab karena hanya cenderung bersifat pragmatis, yang mana hanya untuk meraih kesuksesan materi dan profesi sosial yang akan memakmurkan diri,perusahaan, juga negara. Jika sistem pendidikan tetap seperti ini, walaupun memiliki status pendidikan yang tinggi, maka tidak menjamin mereka sebagai individu- individu yang beradab.

Pendidikan yang bertujuan pragmatis dan ekonomis sebenarnya merupakan pengaruh dari paradigma pendidikan barat yang secular. Tujuan utama pendidikan Agama Islam adalah mencari ridlo Allah SWT, bukan pendidikan pragmatis, akan tetapimemiliki tujuan yang lebih komprehensif dan integratif.

Berangkat dari uraian di atas, penulis merasa tertarik untuk menelitinya dalam tesis dengan judul “ Manajemen Pendidikan Agama Islam dalam Mewujudkan Generasi Berakhlakul Karimah di SMK Negeri 3 Purworejo"dengan harapan dalam penelitan ini dapat memberikan kontribusi yang positif berupa pemikiran yang mana dapat menambah khasanah pemikiran untuk memperbaiki generasi yang berakhlak kharimah di SMK Negeri 3 Purworejo.

\section{KAJIAN LITERATUR}

\section{Manajemen Mutu Pembelajaran}

Menurut Eliyanto, "Manajemen adalah serangkaian kegiatan saling terkait yang meliputi proses perencanaan, pengorganisasian, pengarahan, dan pengendalian dalam mencapai tujuan yang sudah ditetapkan, serta melibatkan orang dan sumber daya organisasi lainnya." 57

Pembelajaran merupakan suatu proses interaksi antara peserta didik dan pendidik dan sumber belajar pada suatu lingkungan belajar. Pembelajaran adalah suatu proses yang kompleks yang didalamnya melibatkan berbagai unsur yang dinamis. ${ }^{58}$

Manajemen mutu merupakan serangkaian kegiatan yang dijalankan dalam manajemen berdasarkan fungsinya masing-masing dan mengikuti tahapan-tahapan tertentu dalam pelaksanaannya. ${ }^{59}$ Pembagian fungsi-fungsi manajemen bertujuan: (1). Supaya sistematika urutan pembahasannya lebih teratur, (2). Agar analisis pembahasannya lebih mudah dan lebih mendalam, (3). Untuk menjadi pedoman

\footnotetext{
${ }^{57}$ Eliyanto, Manajemen dan Kepemimpinan Pendidikan Islam, (Kebumen: Institut Agama Islam Nahdlatul Ulama (IAINU) Kebumen, 2018), hlm. 2.

${ }^{58}$ Aunurrahman, Belajar dan Pembelajaran, (Bandung: Alfabeta, 2009), hlm. 143.

${ }^{59}$ Eliyanto, Op.Cit.
} 
pelaksanaan proses manajemen bagi manajer. Namun demikian, secara umum perbedaan-perbedaan tersebut mempunyai titik temu dalam menyebutkan fungsifungsi manajemen, sebagaimana dalam manajemen mutu William Edwards Deming yaitu: Plan, Do, Check, Act.

PDCA adalah singkatan dari Plan, Do, Check, dan Act yaitu siklus peningkatan proses (Process Improvement) yang berkesinambungan atau secara terus menerus seperti lingkaran yang tidak ada akhirnya. Konsep siklus PDCA (Plan, Do, Check dan Act) ini pertama kali diperkenalkan oleh seorang ahli manajemen kualitas dari Amerika Serikat yang bernama William Edwards Deming.

PDCA (Plan, Do, Check, Act) atau disebut juga filosofi Deming, merupakan manajemen perbaikan mutu secara berkesinambungan, yang menekankan pada keuntungan jangka pendek, menengah, dan panjang. Deming juga mempelopori konsep SPC (Statistical Process Control), yang merupakan konsep dalam perbaikan kualitas berkesinambungan.

Manajemen mutu pembelajaran adalah pemanfaatan sumber daya pembelajaran yang ada, baik faktor yang berasal dari dalam diri individu yang sedang belajar, maupun faktor yang berasal dari luar individu untuk mencapai tujuan pendidikan secara efektif dan efisien. ${ }^{60}$ Manajemen mutu pembelajaran meliputi aktifitas-aktifitas perencanaan, pelaksanaan, evaluasi, dan tindak lanjut hasil pembelajaran.

Manajemen mutu pembelajaran dapat diartikan sebagai usaha dan tindakan kepala sekolah sebagai pemimpin instruksional di sekolah dan usaha maupun tindakan guru sebagai pemimpin pembelajaran di kelas dilaksanakan sedemikian rupa untuk memperoleh hasil dalam rangka mencapai tujuan program sekolah dan juga pembelajaran. Artinya manajemen mutu pembelajaran di sekolah merupakan pengelolaan pada beberapa unit pekerjaan oleh personil yang diberi wewenang untuk itu yang muaranya pada suksesnya program pembelajaran. Keefektifan manajemen mutu pembelajaran dapat dicapai jika fungsi perencanaan, pelaksanaan, evaluasi, dan tindak lanjut hasil pembelajaran.

\section{Pendidikan Agama Islam}

Pendidikan Agama Islam adalah pendidikan mengenai agama Islam. Secara umum, "Pendidikan Agama Islam itu adalah pembentukan kepribadian muslim." Sedangkan secara aplikatif, pendidikan agama Islam artinya mentransformasikan nilainilai Islam terhadap anak didik di lingkungan sekolah, keluarga, dan masyarakat. Selanjutnya, menurut Achmadi, "Pendidikan Agama Islam ialah segala usaha untuk

\footnotetext{
${ }^{60} \mathrm{Ibid}, \mathrm{hlm} .23$.

${ }^{61}$ Zakiah Daradjat, Ilmu Pendidikan Islam, (Jakarta: Bumi Aksara, 2006), hlm. 28.
} 
memelihara dan mengembangkan fitrah manusia serta sumber daya yang ada padanya menuju terbentuknya manusia seutuhnya (insan kamil) sesuai dengan norma Islam." ${ }^{62}$

Pendidikan Agama Islam adalah pendidikan yang berlandaskan pada Al-Qur'an dan AL-Hadits. Pendidikan Agama Islam sebagai sub-sistem pendidikan nasional Indonesia juga tidak terpisahkan dari ideologi Pancasila. Hal tersebut karena nilai-nilai yang terkandung dalam Pancasila secara substansial tidak bertentangan dengan nilainilai dasar ajaran Islam.

Ilmu pendidikan Islam memberikan pengetahuan dasar tentang wahyu Allah SWT. Melalui kajian Al-Qur'an yang tersirat banyak implikasi pendidikan, manusia dapat belajar dan memiliki pedoman hidup ke arah yang benar. Sumber pendidikan Islam selain Al Qur'an yaitu Al-Hadits, yang berisi penjelasan pengamalan nilai-nilai ibadah yang kontekstual dengan dinamika kehidupan umat manusia. Sedangkan sumber-sumber yang lain hanya dapat dijadikan suplemen pendukung validitas sumber Islami tersebut. ${ }^{63}$

Abu Ahmadi \& Nur Uhbiyati mengemukakan bahwa, "tujuan pendidikan Islam adalah terbentuknya anak didik menjadi hamba Allah yang takwa dan bertanggungjawab melaksanakan pekerjaan duniawi dan ukhrawi."64 Untuk itu, maka sudah tentu pendidikan Islam sumber materi pokoknya adalah isi Al-Qur'an dan Al-Hadits, yang mengajarkan tentang akidah, syari'at, dan akhlak (cara hidup Islami).

\section{Akhlakul Karimah}

“Akhlakul karimah ialah segala tingkahlaku yang terpuji (mahmudah) juga bisa dinamakan (fadhilah)." 65 Jadi (akhlak karimah) berarti tingkah laku yang terpuji yang merupakan tanda kesempurnaan iman seseorang kepada Allah. ${ }^{66}$ (akhlak karimah) di lahirkan berdasarkan sifat-sifat dalam bentuk perbuatan-perbuatan yang sesuai dengan ajaran-ajaran yang terkandung dalam AL-Qur'an dan AL-Hadis.

Menurut M. Yatimin Abdullah, "akhlakul karimah yaitu segala tingkah laku yang terpuji atau baik." 67 Lebih lanjut dikatakan bahwa, akhlak yang baik dilahirkan oleh sifat-sifat yang baik pula. Dalam hal ini, baik berarti sesuatu yang pantas dikerjakan dan diusahakan atau dikehendaki, yang memenuhi hasrat dasar manusia.

Akhlakul karimah yaitu tingkah laku yang terpuji yang merupakan tanda kesempurnaan iman seseorang kepada Allah. Akhlakul karimah dilahirkan berdasarkan

\footnotetext{
${ }^{62}$ Achmadi, Ideologi Pendidikan Islam, (Yogyakarta: Pustaka Pelajar, 1993), hlm. 28.

${ }^{63}$ Eliyanto, Pendidikan Aqidah Akhlak, (Yogyakarta: Program Studi MPI UIN Sunan Kalijaga Yogyakarta, 2017), hlm. 41.

${ }^{64}$ Abu Ahmadi \& Nur Uhbiyati, Ilmu Pendidikan.. (Jakarta: Rineka Cipta, 2001), hlm. 115.

${ }^{65}$ Atang Abdul Hakim dan Jaih Mubarok, Metodologi Studi Islam, (Bandung: Rosda Karya, 2007), hlm. 200.

${ }^{66}$ A.Zainuddin dan Muhammad Jamhari, AlIslam 2: Muamalah dan Akhlak, (Bandung: Pustaka Setia, 1999), hlm. 78 .
}

${ }^{67}$ Muhammad Yatimin Abdullah, Studi Akhlak dalam Perspektif Al Qur'an, (Jakarta: Amzah., 2008), hlm. 38. 
sifat-sifat yang terpuji. ${ }^{68}$ "Ruang lingkup ajaran Akhlakul Karimah mencangkup berbagai aspek, dimulai dari Akhlakul Karimah terhadap Allah, manusia, dan lingkungannya."69 Alkhlakul karimah merupakan akhlaknya setiap mukmin. Menurut Al-Ghazali (dalam M. Yatimin Abdullah), terdapat empat pokok keutamaan akhlakul karimah, yaitu: (1) mencari hikmah; (2) bersikap berani; (3) bersuci diri; dan berlaku adil. ${ }^{70}$

Dengan demikian, berdasar pada teori-teori di atas, maka dapat disimpulkan bahwa akhlakul karimah yaitu segala tingkah laku yang baik, yaitu yang didasari pada nilai-nilai keimanan kepada Allah SWT.

\section{METODE PENELITIAN}

Jenis penelitian ini yaitu kualitatif, pendekatan yang lebih menekankan pada aspek pemahaman secara mendalam terhadap suatu masalah manusia dan sosial. Waktu penelitian adalah antara 1 Juni 2019 sampai dengan 1 September 2019, dan tempat penelitian adalah di SMK Negeri 03 Purworejo.

Subjek dan informan penelitian ini yaitu orang-orang yang berhubungan dengan manajemen pendidikan agama Islam dalam mewujudkan generasi berakhlakul karimah, yaitu: kepala sekolah, wakil kepala sekolah, guru, karyawan, komite sekolah dan siswa dan komponen lainya yang terlibat dalam stuktur organisasi di SMK Negeri 03 Purworejo.

Teknik pengumpulan data merupakan cara yang digunakan peneliti untuk memperoleh data penelitian yang dibutuhkan. Proses pengumpulan data dalam penelitian ini dilakukan dengan: observasi, wawancara mendalam, dan dokumentasi.

Dalam menguji keabsahan data peneliti menggunakan tehnik Triangulasi, yakni teknik pemeriksaan keabsahan data yang memanfaatkan sesuatu yang lain diluar data untuk keperluan pengecekan atau sebagai pembanding terhadap data itu.ltu artinya melakukan validasi, dengan cara mengecek dokumen program dan bukti tertulis lainnya. ${ }^{71}$ Dalam penelitian ini menggunakan Triangulasi metode yaitu menggunakan dua strategi yaitu: (1) Pengecekan terhadap derajat kepercayaan penemuan hasil penelitian dengan beberapa tehnik pengumpulan data; (2) Pengecekan derajat kepercayaan beberapa sumber data dengan metode yang sama.

Langkah-langkah yang dilakukan penulis lakukan untuk menganalisis data yang sudah diperoleh dari hasil observasi, wawancara, dan dokumentasi yaitu dengan menggunakan model analisis data Miles dan Huberman sebagaimana yang dikutip oleh

\footnotetext{
${ }^{68}$ Abdullah Rasyid, Aqidah Akhlak, (Bandung: Husaini, 1989), hlm. 73.

${ }^{69}$ Muhammad Alim, Pendidikan Agama Islam, (Bandung: Raja Grafindo Persada, 2006), hlm. 152-158.

${ }^{70}$ Muhammad Yatimin Abdullah, Op.Cit., hlm. 40-41.

${ }^{71}$ Patton, Michael Quinn. Metode Evaluasi Kualitatif. (Yogyakarta: Pustaka Pelajar, 2006), hal. 280.
} 
Sugiyono, yaitu reduksi data (data reduction), penyajian data (data display), dan penarikan kesimpulan (conclusion drawing/verification). ${ }^{72}$

\section{HASIL PENELITIAN DAN PEMBAHASAN}

\section{Perencanaan Pembelajaran PAI dalam Mewujudkan Generasi Berakhlakul} Karimah di SMK N 3 Purworejo

Perencanaan dilakukan untuk menetapkan sejumlah pekerjaan yang harus dilaksanakan kemudian. Setiap manajer dituntut terlebih dahulu agar mereka membuat rencana tentang aktivitas yang harus dilakukan. Perencanaan tersebut merupakan aktivitas untuk memilih dan menghubungkan fakta serta aktifitas membuat dan menggunakan dugaan mengenai masa yang akan datang dalam hal merumuskan aktifitas yang direncanakan.

Manfaat perencanaan pembelajaran adalah untuk memudahkan pembuatan persiapan pembelajaran dan memudahkan pengembangan pembelajaran yang aktif, kreatif, efektif dan menyenangkan. ${ }^{73}$ Mengacu kepada teori Teguh Triwiyanto tersebut, dapat dilihat bahwa pembuatan perencanaan dalam pembelajaran PAI dalam mewujudkan generasi berakhlakul karimah di SMK N 3 Purworejo sangat diperlukan dalam upaya mendidik siswa sesuai dengan visi, misi dan tujuan sekolah. Oleh karena itu, agar tidak menyimpang dari tujuan, maka sangat penting dalam pembelajaran PAI untuk membuat perencanaan sebelum melaksanakan kegiatan pembelajaran.

Berdasarkan hasil temuan dilapangan, terungkap bahwa perencanaan pembelajaran PAI dalam mewujudkan generasi berakhlakul karimah di SMK N 3 Purworejo dilakukan sebelum pembelajaran awal tahun dimulai. Sebelum kegiatan pembelajaran di awal tahun dimulai, kepala sekolah mengumpulkan para guru pengampu PAI untuk diberikan pengarahan terkait dengan tujuan pembelajaran, target materi, dan ruang lingkup materi selama satu tahun ke depan.

Dalam hal pembuatan perangkat mengajar, kepala sekolah telah membuat garis besar dan targetnya. Perencanaan pembelajaran PAI dilakukan oleh semua guru PAI dengan membuat perangkat mengajar secara tertulis, yaitu berupa: Program tahunan, Program semester, Silabus dan RPP menyesuaikan dengan materi dan arahan kepala sekolah.

2. Pelaksanaan Pembelajaran PAI dalam Mewujudkan Generasi Berakhlakul Karimah di SMK N 3 Purworejo

Pelaksanaan (actuating) adalah kata lain dari direction (bimbingan/pengarahan) dan merupakan fungsi manajemen yang tidak dapat dilepaskan dari beberapa fungsi manajemen yang lainnya, serta saling berhubungan erat antara yang satu dengan yang lainnya. Aktivitas pengarahan adalah suatu kegiatan yang berhubungan dengan pemberian perintah dan saran. Hal ini mengandung permasalahan dalam menunjukkan

\footnotetext{
${ }^{72}$ Sugiyono, Metode Penelitian Pendidikan, (Bandung: Alfabeta. 2009), hal. 254.

${ }^{73}$ Teguh Triwiyanto, Manajemen Kurikulum dan Pembelajaran, (Jakarta: Bumi Aksara, 2015), hlm. 97.
} 
rencana yang penting kepada bawahan yang bertanggung jawab untuk melaksanakannya. Selain itu penting juga hubungan individual setiap saat diantara manajer dan para bawahannya yang telah terikat dalam organisasi.

"Pelaksanaan atau pengarahan (actuating) merupakan usaha yang berhubungan dengan segala sesuatu agar semuanya dapat dilakukan." "P4 "Pelaksanaan kurikulum dan pembelajaran secara sinergis dapat mempercepat dan menghasilkan pencapaian sesuai dengan tujuan pendidikan." 75

Tindakan pelaksanaan (actuating) pembelajaran PAI di SMK N 3 Purworejo mencakup: motivasi, kepemimpinan, komunikasi, latihan dan bentuk-bentuk pengaruh pribadi lainnya. Dimana hal tersebut diberikan oleh kepala sekolah dan guru PAI.

a. Motivasi

Motivasi dari seorang pemimpin merupakan penggerak kekuatan yang besar bagi setiap bawahan. Begitu pula pembelajaran PAI dalam mewujudkan generasi berakhlakul karimah di SMK N 3 Purworejo akan memiliki pengaruh yang besar manakala kepala sekolah terjun langsung memberikan pengarahan dan motivasi baik kepada semua guru dan karyawan serta siswa akan pentingnya akhlakul karimah. Pemberian motivasi dalam Pembelajaran PAI adalah sebagai upaya untuk mewujudkan visi, misi dan tujuan SMK N 3 Purworejo, supaya para siswa dan alumninya memiliki akhlakul karimah.

Berdasarkan hasil wawancara dan observasi lapangan di SMK N 3 Purworejo, peneliti dapat mengambil kesimpulan bahwa pemberian Motivasi kepada para guru dan siswa maupun dari para guru kepada siswa di SMK N 3 Purworejo terkait pentingnya akhlakul karimah dilakukan secara langsung. Kegiatan motivasi ini dilakukan tidak terjadwal, tetapi dilaksanakan sesuai dengan kebutuhan.

b. Kepemimpinan

Kepemimpinan pembelajaran memiliki peran penting dalam membangun kecerdasan siswa. Melalui kepemimpinan pembelajarn yang baik, akan dicapai kesiapan dan kesanggupan siswa untuk mampu dan tanggap terhadap perubahan serta kebutuhan masyarakat yang semakin kompleks. Pembangunan dan peningkatan kualitas SDM yang memiliki kepribadian muslim seutuhnya perlu dibangun melalui kepemimpinan pembelajaran yang baik. Dalam hal ini kepala sekolah dan guru merupakan pemimpin instruksional atau pemimpin pembelajaran.

Berdasarkan hasil wawancara dan observasi, peneliti mendapatkan temuan bahwa pengarahan pembelajaran PAI di SMK N 3 Purworejo dilakukan secara langsung oleh kepala sekolah. Pengarahan pembelajaran untuk guru mata pelajaran PAI dilakukan oleh guru-guru PAI di SMK N 3 Purworejo, yaitu berjumlah 3 orang. Kepemimpinan ayng dilakukan oleh guru di dalam pembelajaran PAI dalam

\footnotetext{
${ }^{74}$ Sukanto Reksohadiprodjo, Dasar-Dasar Manajemen, (Yogjakarta: BPFE Yogyakarta, 2015), hlm. 49.

${ }^{75}$ Teguh Triwiyanto, Op.Cit., hlm. 166.
} 
mewujudkan generasi berakhlakul karimah di SMK N 3 Purworejo telah dilaksanakan sesuai dengan perencanaan, yaitu dengan adanya Musyawarah Guru Mata Pelajaran (MGMP) di dalam membuat perencanaan dan pelaksanaan pembelajaran PAI, dengan kepala sekolah sebagai ketuanya.

c. Komunikasi

Dalam upaya pembiasaan akhlakul karimah, kepala sekolah selalu bekerja sama dengan seluruh dewan guru dan karyawan untuk memberikan pengawasan dan pendampingan terhadap para siswa dalam bertingkah laku setiap hari. Dalam hal ini beliau kepala SMK N 3 Purworejo selalu memberikan arahan kepada para guru untuk membina para siswa sesuai dengan materi dalam pembelajaran PAI dalam bentuk rapat pembinaan.

Peneliti mendapatkan temuan bahwa komunikasi antara kepala sekolah dengan guru pengajar PAI (khususnya) dalam kaitannya mewujudkan generasi berakhlakul karimah siswa telah terjalin dengan lancar. Ini terbukti dengan adanya rapat pembinaan dengan segenap guru dan karyawan. Dalam pertemuan ini, kepala sekolah menyampaikan materi-materi penting yang berkaitan dengan akhlakul karimah siswa. Ini berarti bahwa tugas dalam mewujudkan generasi berakhlakul karimah siswa dan pendampingannya bukan hanya tugas guru mata pelajaran PAI saja, tetapi tugas untuk semua personil yang ada di SMK N 3 Purworejo.

Komunikasi antara guru PAI dengan siswa dalam kaitannya mewujudkan generasi berakhlakul karimah juga telah terjalin dengan lancar. Ini terbukti dengan tidak adanya kendala yang berarti selama pelaksanaan pembelajaran PAI.

d. Latihan

Dalam upaya mewujudkan generasi berakhlakul karimah, guru PAI di SMK N 3 Purworejo sangat berperan aktif dalam mendidik siswa. Mereka benar-benar dituntut untuk dapat menjadi teladan yang baik bagi siswa. Guru yang mengajar PAI di SMK N 3 Purworejo adalah guru yang latar belakang pendidikannya PAI dan pernah belajar di pondok pesantren.

Setelah peneliti mengadakan wawancara dengan beberapa narasumber sebagaimana telah dideskripsikan di depan, maka dapat diketahui tentang bagaimana caranya agar hasil pembelajaran PAI benar-benar dapat mewujudkan generasi berakhlakul karimah di SMK N 3 Purworejo yaitu sebagai berikut:

1) Guru selalu mengadakan kontrol secara berkelanjutan terhadap sikap dan perilaku siswa setiap saat.

2) Ajaran akhlakul karimah siswa dituangkan dalam tata tertib siswa dan masuk dalam penilaian aspek afektif.

3) Apabila terjadi penyimpangan, guru memberikan hukuman, baik secara ringan, sedang, maupun berat.

4) Menjadikan akhlak siswa sebagai salah satu standar kenaikan kelas dan Sandar Kompetensi Lulusan (SKL). 
5) Adanya kontrol terhadap perilaku siswa dan teguran langsung dari guru dan kepala sekolah.

Pelaksanaan pembelajaran PAI dalam mewujudkan generasi berakhlakul karimah di SMK N 3 Purworejo telah berjalan sesuai standard yang telah ditetapkan. Pelaksanaan pembelajaran dilakukan sesuai dengan kalender pendidikan, jadwal yang telah ditentukan, dan sesuai dengan Rencana Pelaksanaan Pembelajaran (RPP) yang telah dibuat. Metode pembelajaran yang digunakan oleh guru juga variatif, menyesuaikan keadaan dan kemampuan peserta didik.

\section{Evaluasi Pembelajaran PAI dalam Mewujudkan Generasi Berakhlakul Karimah di SMK N 3 Purworejo}

Evaluasi dilakukan untuk melihat hasil pembelajaran yang telah dilakukan. Evaluasi penting dilakukan guna melihat keberhasilan pembelajaran. Menurut Eliyanto, melalui evaluasi akan diketahui kinerja guru dan prestasi siswa. Lebih lanjut, bahwa proses evaluasi harus valid dan reliabel guna mencapai objektivitas. ${ }^{76}$

Menurut Teguh Triwiyanto, "Evaluasi atau penilaian adalah proses sistematis yang meliputi pengumpulan informasi (angka, deskripsi, dan verbal), analisis, interpretasi informasi untuk membuat keputusan." Lebih lanjut, penilaian dilakukan oleh: (a) pendidik (internal), direncanakan dan dilakukan oleh pendidik saat proses pembelajaran (penjaminan mutu); (b) satuan pendidikan (internal); dan (c) menilai pencapaian SKL atau sebagai dasar pertimbangan kelulusan, dilakukan oleh pemerintah (eksternal) sebagai pengendali mutu. ${ }^{77}$

Evaluasi dilakukan untuk mengetahui sejauh mana keberhasilan, efektivitas, dampak, dan manfaat pembelajaran. Para guru PAI di SMK N 3 Purworejo melakukan penilaian/evaluasi terhadap hasil belajar santri dalam pembelajaran PAI dalam mewujudkan generasi berakhlakul karimah. Para guru yang mengajar PAI di SMK N 3 Purworejo melaksanakan penilaian terhadap keberhasilan pembelajaran PAI dengan beberapa cara di antaranya adalah dengan adanya ujian/test tertulis (penilaian harian dan akhir semester) dan penilaian sikap/akhlak siswa dalam kehidupan sehari-hari.

Standar keberhasilan dalam pembelajaran PAI diukur berdasarkan KKM yang telah ditentukan. Penilaian meliputi aspek kognitif, afektif, dan psikomotorik. Siswa dikatakan berhasil apabila secara penilaian tertulis sudah melebihi batas Kriteria Ketuntasan minimal (KKM), dan secara afektif telah memiliki sikap akhlakul karimah. Bukti-bukti keberhasilan pembelajaran PAI dalam mewujudkan generasi berakhlakul karimah di SMK N 3 Purworejo yaitu dapat dilihat secara nyata dari akhlak terpuji dari para siswa.

\section{Tindak lanjut Pembelajaran PAI dalam Mewujudkan Generasi Berakhlakul Karimah di SMK N 3 Purworejo}

\footnotetext{
${ }^{76}$ Eliyanto, Op.Cit.

${ }^{77}$ Teguh Triwiyanto, Op.Cit., hlm. 189.
} 
Tindak lanjut merupakan suatu fungsi manajemen mutu pembelajaran. Tindak lanjut hasil evaluasi pembelajaran yaitu pelaporan. Pelaporan pembelajaran adalah suatu bentuk pertanggungjawaban atas proses pembelajaran yang telah dilakukan. Pelaporan berisi informasi yang ditulis untuk disampaikan kepada seseorang atau suatu badan karena tanggung jawab. Setiap guru atau pendidik perlu membuat pelaporan pembelajaran guna mengetahui kemajuan hasil belajar peserta didiknya. Melalui laporan pembelajaran akan diketahui kemajuan hasil pembelajaran. ${ }^{78}$

a. Pelaporan akhir semester kepada pimpinan/kepala sekolah

Pelaporan merupakan suatu kegiatan yang dilakukan untuk menyampaikan halhal yang berhubungan dengan hasil pekerjaan yang telah dilakukan selama satu periode tertentu. Pelaporan pembelajaran PAI di SMK N 3 Purworejo dilakukan oleh guru PAI sebagai bentuk tanggung jawab. Pelaporan hasil pembelajaran dilakukan setiap semester secara tertulis. Hasil pembelajaran PAI berupa penilaian, yang kemudian direkap untuk dimasukkan ke dalam buku raport siswa.

b. Pelaporan akhir semester kepada orang tua/wali siswa

Laporan yang dibuat oleh guru untuk siswa dan orang tua berisi catatan prestasi belajar siswa. Catatan itu dapat dibedakan menjadi dua, yaitu naik kelas atau tidak naik kelas dan lulus atau tidak lulus. Prestasi siswa yang dilaporkan guru kepada siswa dan orang tua dapat dilihat dalam buku rapor yang diisi pada setiap semester. Pada proses pengambilan raport, selain untuk mengadakan serah terima dokumen hasil belajar, juga bertujuan untuk mendiskusikan proses belajar siswa dengan orang tuanya.

Dalam hal ini, setiap guru mata pelajaran PAI di SMK N 3 Purworejo membuat laporan perkembangan hasil belajar siswa selama kurun waktu tertentu, mulai dari penilaian harian, midlle semester dan penilaian akhir semester. Pelaporan hasil belajar siswa di SMK N 3 Purworejo kepada orang tua/wali siswa dilakukan pada setiap akhir semester. Wali siswa diundang ke sekolah untuk menerima laporan dari masing-masing wali kelas tentang perkembangan belajar putra-putrinya.

Pelaporan penilaian hasil pembelajaran siswa dilakukan satu tahun dua kali dalam setiap semester. Pelaporan dilakukan secara langsung kepada wali siswa baik secara lisan maupun tertulis. Laporan secara lisan disampaikan oleh para wali kelas secara langsung kepada orang tua/wali siswa pada saat pengambilan buku laporan hasil belajar (raport). Sedangkan laporan secara tertulis disampaikan dengan menyerahkan hasil penilaian berupa raport siswa.

\section{KESIMPULAN}

\footnotetext{
${ }^{78}$ Suharsimi Arikunto, Evaluasi Program Pendidikan: Pedoman Teoretis Praktis bagi Mahasiswa dan Praktisi Pendidikan, (Jakarta: Bumi Aksara, 2010), hlm. 223.
} 
Berdasarkan hasil penelitian di depan maka dapat penulis tuliskan lima temuan sebagai berikut:

1. Perencanaan Pembelajaran PAI dalam Mewujudkan Generasi Berakhlakul Karimah di SMK N 3 Purworejo

Perencanaan pembelajaran PAI dalam mewujudkan generasi berakhlakul karimah di SMK N 3 Purworejo dilakukan sebelum pembelajaran awal tahun dimulai. Para guru PAI mengumpulkan rencana pelaksanaan pembelajaran untuk disetujui kepala sekolah. Para guru PAI membuat perangkat mengajar, yaitu membuat persiapan dengan membuat Program tahunan, Program semester, Silabus dan RPP menyesuaikan dengan materi dan arahan kepala sekolah.

2. Pelaksanaan Pembelajaran PAI dalam Mewujudkan Generasi Berakhlakul Karimah di SMK N 3 Purworejo

Pelaksanaan pembelajaran PAI dalam mewujudkan generasi berakhlakul karimah di SMK N 3 Purworejo telah berjalan sesuai dengan standar yang telah ditetapkan sekolah. Dalam pelaksanaan pembelajaran, para guru mata pelajaran PAI di SMK N 3 Purworejo telah melakukan proses pembelajaran sesuai dengan apa yang telah dipersiapan sebelumnya. Pelaksanaan pembelajaran dilakukan sesuai dengan kalender pendidikan, jadwal yang telah ditentukan, dan sesuai dengan Rencana Pelaksanaan Pembelajaran (RPP) yang telah dibuat.

Metode pembelajaran PAI yang digunakan oleh guru dalam mewujudkan generasi berakhlakul karimah di SMK N 3 Purworejo menyesuaikan keadaan dan kemampuan peserta didik. Model pembelajaran yang digunakan juga variatif dan mereka menggunakan media pembelajaran, sehingga tidak terjadi pembelajaran yang monoton.

3. Evaluasi Pembelajaran PAI dalam Mewujudkan Generasi Berakhlakul Karimah di SMK N 3 Purworejo

Evaluasi/Penilaian terhadap keberhasilan pembelajaran PAI dalam mewujudkan generasi berakhlakul karimah dilakukan oleh guru/pendidik. Para guru yang mengajar PAI melakukan evaluasi dengan beberapa cara, di antaranya adalah dengan adanya ujian/test tertulis (penilaian harian dan akhir semester) dan penilaian akhlak siswa dalam kehidupan sehari-hari.

Standar yang dijadikan sebagai alat ukur penilaian keberhasilan siswa dalam belajar pembelajaran PAI dalam mewujudkan generasi berakhlakul karimah di SMK N 3 Purworejo meliputi aspek kognitif, afektif, dan psikomotorik. Kriteria keberhasilan pembelajaran PAI yaitu apabila secara penilaian tertulis siswa sudah mencapai atau melebihi batas Kriteria Ketuntasan minimal (KKM), dan secara akhlak telah mmiliki sikap akhlakul karimah.

4. Tindak lanjut Pembelajaran PAI dalam Mewujudkan Generasi Berakhlakul Karimah di SMK N 3 Purworejo

Sebagai langkah tindak lanjut hasil evaluasi, maka setiap guru di SMK N 3 Purworejo melaporkan hasil pembelajaran PAI yang diampu. Tindak lanjut hasil 
pembelajaran dilakukan setiap semester secara tertulis. Hasil pembelajaran yang berupa penilaian akan direkap untuk dimasukkan ke dalam buku Raport. Selanjutnya, sekolah memberikan laporan hasil pembelajaran siswa kepada orang tua/wali siswa pada setiap semester. Wali siswa diundang ke sekolah untuk menerima laporan dari masing-masing wali kelas tentang perkembangan belajar putra-putrinya.

Pelaporan penilaian hasil pembelajaran PAI dilakukan satu tahun dua kali dalam setiap semester. Pelaporan dilakukan secara langsung kepada wali siswa baik secara lisan maupun tertulis. Laporan secara lisan disampaikan oleh para wali kelas secara langsung kepada orang tua/wali siswa pada saat pengambilan buku laporan hasil belajar (raport). Sedangkan laporan secara tertulis disampaikan dengan menyerahkan hasil penilaian berupa raport siswa.

\section{DAFTAR PUSTAKA}

Abdullah Nasih Ulwan, 1981, Pedoman Pendidikan Anak dalam Islam, Semarang: Asy Syifa'.

Abdullah Rasyid, 1989, Aqidah Akhlak, Bandung: Husaini.

Abu Ahmadi \& Nur Uhbiyati, 2001, Ilmu Pendidikan.. Jakarta: Rineka Cipta.

Achmadi, 1993, Ideologi Pendidikan Islam, Yogyakarta: Pustaka Pelajar.

Atang Abdul Hakim dan Jaih Mubarok, 2007, Metodologi Studi Islam, Bandung: Rosda Karya.

Aunurrahman (2009), Belajar dan Pembelajaran, Bandung: Alfabeta.

A.Zainuddin dan Muhammad Jamhari, 1999, AlIslam 2: Muamalah dan Akhlak, Bandung: Pustaka Setia.

Departemen Pendidikan Nasional, 2003, Standar Kompetensi PendidikanAgama Islam, Jakarta: Depdiknas.

Dirjen Binbaga Agama Islam Depag RI, 2002, Metodologi pendidikan Agama Islam, Jakarta: Depag RI.

Eliyanto, (2018) Manajemen dan Kepemimpinan Pendidikan Islam, Kebumen: Institut Agama Islam Nahdlatul Ulama (IAINU) Kebumen.

, (2017) Pendidikan Aqidah Akhlak, Yogyakarta: Program Studi MPI UIN Sunan Kalijaga Yogyakarta.

Jaudah Muhammad Awwad, 1995, Mendidik Anak Secara Islami, Jakarta: Gema Insan.

Muhammad Alim, 2006, Pendidikan Agama Islam, Bandung: Raja Grafindo Persada.

Muhammad Yatimin Abdullah, 2008, Studi Akhlak dalam Perspektif Al Qur'an, Jakarta: Amzah.

Patton, Michael Quinn, (2006), Metode Evaluasi Kualitatif, Yogyakarta: Pustaka Pelajar.

Rose Mini dan A. Priyanto, 2003, Perilaku Usia Dini Kasus danPemecahannya. Yogyakarta: Kanisius.

Sugiyono, (2009), Metode Penelitian Pendidikan, Bandung: Alfabeta.

Suharsimi Arikunto, 2010, Evaluasi Program Pendidikan: Pedoman Teoretis Praktis bagi Mahasiswa dan Praktisi Pendidikan, Jakarta: Bumi Aksara.

Sukanto Reksohadiprodjo, 2015, Dasar-Dasar Manajemen, Yogjakarta: BPFE Yogyakarta. 
Sulistyorini, 2009, ManajemenPendidikan Islam, Yogyakarya: Teras.

Teguh Triwiyanto, 2015, Manajemen Kurikulum dan Pembelajaran, Jakarta: Bumi Aksara. Umar Tirtarahardja dan La Sula, 2000, Pengantar Pendidikan, Jakarta: Rineka Cipta.

Zakiah Daradjat, 2006, IImu Pendidikan Islam, Jakarta: Bumi Aksara. 